\title{
HUBUNGAN KEBIASAAN SARAPAN, KECUKUPAN ZAT GIZI DAN CAIRAN DENGAN DAYA KONSENTRASI ANAK SEKOLAH DASAR
}

\author{
Association between Breakfast Habit, Nutrition and Fluid Adequacy with Learning \\ Concentration of Elementary Students \\ Wida Ratna Yunita ${ }^{1}$, Triska Susila Nindya ${ }^{2}$ \\ ${ }^{1}$ Program Studi S1 Kesehatan Masyarakat, Fakultas Kesehatan Masyarakat, Universitas Airlangga, Surabaya \\ ${ }^{2}$ Departemen Gizi Kesehatan, Fakultas Kesehatan Masyarakat, Universitas Airlangga, Surabaya
}

\begin{abstract}
ABSTRAK
Kebiasaan sarapan, kecukupan zat gizi serta cairan dapat membantu meningkatkan daya konsentrasi anak sekolah. Tujuan penelitian ini adalah menganalisis hubungan kebiasaan sarapan, kecukupan zat gizi dan cairan dengan daya konsentrasi pada anak sekolah. Penelitian ini adalah observasional dengan desain cross sectional, bertempat di SDN Sukomanunggal IV Surabaya dengan responden sebanyak 60 siswa. Data yang dikumpulkan meliputi karakteristik responden, kebiasaan sarapan, konsumsi zat gizi, konsumsi cairan, dan tes daya konsentrasi. Kebiasaan sarapan diukur dengan menggunakan kuesioner. Asupan zat gizi dan cairan diukur dengan menggunakan recall selama 3x24 jam dan daya konsentrasi diukur dengan menggunakan tes bender gestalt yang dilakukan oleh psikolog. Data di analisis menggunakan uji chi square dan regresi logistik. Hasil penelitian menunjukkan $60 \%$ responden terbiasa sarapan. Kecukupan zat gizi yang memiliki tingkat kecukupan yang baik adalah karbohidrat $(63,3 \%)$, protein $(60,0 \%)$, lemak $(61,7 \%)$ dan vitamin C (58,3\%), sedangkan yang tidak cukup yaitu energi $(51,7 \%)$, zat besi $(53,3 \%)$ dan cairan $(56,7 \%)$. Lebih dari separuh daya konsentrasi responden tergolong tinggi $(65,0 \%)$. Ada hubungan antara kebiasaan sarapan, tingkat kecukupan energi, karbohidrat, protein, Fe, vitamin $\mathrm{C}$ dan cairan dengan daya konsentrasi. Tidak ada hubungan antara tingkat kecukupan lemak dengan daya konsentrasi. Oleh karena itu orang tua siswa perlu membiasakan menyediakan sarapan secara rutin
\end{abstract}

Kata kunci: cairan, daya konsentrasi, kebiasaan sarapan, tingkat kecukupan zat gizi

\begin{abstract}
Breakfast habits, nutritional and fluid adequacy is very important for students learning concentration. The purpose of this research was to analyze the relationship between breakfast habits, nutritional and fluid adequacy with the learning concentration in students. This was an observational research with cross sectional design, conducted in SDN Sukomanunggal IV Surabaya with 60 respondents. Characteristics of respondents, breakfast habit, food intake, fluid intake and learning concentration test were collected. The breakfast habit was measured by questionnaire. The nutrition and fluid intake were measured using recall $3 \times 24$ hours and the concentration was measured by using bender gestalt test. The data was analyzed by chi square test and logistic regression. Respondents have an adequate of carbohydrate (63.3\%), protein (60.0\%), fat (61.7\%) and vitamin C (58.3\%). Meanwhile inadequate of energy (51.7\%), iron (53.3\%) and fluid (56.7\%). There are significant correlation between breakfast habit, energy, carbohydrate, protein, Fe, vitamin $C$ and fluid adequacy level with learning concentration. There was no significant correlation between fat adequacy level with learning concentration. Therefore parents need to provide the breakfast regularly.
\end{abstract}

Keywords: fluid, concentration, breakfast habit, nutrition adequacy level

\section{PENDAHULUAN}

Zat gizi yang adekuat dan seimbang mempunyai pengaruh terhadap pertumbuhan dan perkembangan, terutama pada saat usia sekolah dimana anak sedang mengalami pertumbuhan yang sangat pesat. Pertumbuhan anak usia sekolah dasar berlangsung secara terus menerus, oleh karena itu terjadi peningkatan asupan makanan. Agar daya tahan tubuh anak tetap terjaga selama mengikuti kegiatan di sekolah maupun kegiatan ekstrakurikuler, maka anak perlu ditunjang dengan pangan yang bergizi dan berkualitas (Syahnur, dkk., 2013). 
Pola konsumsi anak telah menjadi perhatian khusus karena pola makan pada awal kehidupan cenderung akan menetap hingga masa dewasa. Salah satu upaya untuk memenuhi kebutuhan energi anak sekolah adalah sarapan pagi. Meninggalkan sarapan atau konsumsi sarapan yang tidak memadai dapat menjadi faktor yang berpengaruh pada ketidakcukupan gizi (Soedibyo dan Gunawan, 2009). Sarapan memberikan asupan energi untuk otak yang paling baik agar dapat berkonsentrasi dan memudahkan menyerap pelajaran di sekolah, sehingga prestasi belajar menjadi baik. Ketika bangun pagi, gula darah dalam tubuh rendah karena semalaman tidak makan. Pada umumnya sarapan menyumbangkan energi sebesar $25 \%$ dari kebutuhan gizi sehari. Tanpa sarapan yang cukup, otak akan sulit berkonsentrasi di sekolah (Syahnur, dkk., 2013). Sarapan dapat memenuhi kecukupan energi sehari sebanyak 15-30\% (Hardinsyah \& Aries, 2012).

Manusia membutuhkan air minimal 1,5 liter - 2 liter per hari atau 8-12 gelas sehari. Cairan menjaga fungsi otak dengan baik misalnya menjaga daya konsentrasi, berpikir lebih cepat dan tidak mudah lupa. Kurangnya konsumsi cairan merupakan salah satu penyebab rentannya anak mengalami dehidrasi. Konsumsi cairan anak sebagian besar (79\%) diperoleh dari minuman dan sisanya $(21 \%)$ dari makanan. Keadaan dehidrasi terkait dengan aspek fungsi kognitif salah satunya adalah konsentrasi (Lentini dan Margawati, 2014).

Masalah gizi anak usia sekolah dasar merupakan dampak dari ketidakseimbangan antara asupan makan dan zat gizi yang dikeluarkan oleh tubuh. Penelitian ini dilakukan agar dapat menganalisis hubungan kebiasaan sarapan, tingkat kecukupan zat gizi dan cairan dengan daya konsentrasi anak sekolah dasar.

\section{METODE}

Penelitian ini telah lulus kaji etik pada komisi etik penelitian kesehatan Fakultas Kesehatan Masyarakat Universitas Airlangga No. 299KEPK. Penelitian ini merupakan penelitian analitik observasional dengan menggunakan metode cross sectional. Populasi yang digunakan pada penelitian ini adalah semua murid dari kelas 4 dan kelas 5 di SDN Sukomanunggal 4 Surabaya yang berjumlah 60 siswa. Jumlah responden yang diikutsertakan dalam penelitian ini adalah seluruh populasi siswa. Pengumpulan data dilakukan melalui wawancara menggunakan kuesioner untuk mengetahui karakteristik, kebiasaan sarapan dan jenis menu makanan yang dikonsumsi saat sarapan selama 3 hari berturut-turut. Kebiasaan sarapan dibagi menjadi 2 kategori, terbiasa sarapan apabila $\geq 4$ kali dalam seminggu dan tidak terbiasa sarapan apabila $\leq 3$ kali dalam seminggu. Recall $3 \times 24$ jam untuk mendapatkan data tentang tingkat kecukupan zat gizi dan cairan. Untuk kecukupan zat gizi tergolong cukup apabila $\geq 77 \%$ dari AKG dan tergolong kurang apabila $\leq 77 \%$ dari AKG. Asupan cairan tergolong cukup apabila $\geq 1,8 \mathrm{~L} /$ hari dan tergolongan kurang apabila $<1,8 \mathrm{~L} /$ hari, kecukupan cairan didapat dari konsumsi makanan maupun minuman. Tes bender gestal untuk mengukur daya konsentrasi dibagi menjadi kategori tinggi apabila skor 0-7 dan kategori rendah apabila skor 8-14. Penelitian ini dilakukan pada saat jam istirahat. Data sekunder untuk mengetahui data dokumen sekolah, nama dan tanggal lahir.

Uji chi square dilakukan untuk menganalisis hubungan antar variabel analisis regresi logistik dilakukan untuk mengetahui faktor yang paling berpengaruh terhadap daya konsentrasi belajar.

\section{HASIL DAN PEMBAHASAN}

Hampir separuh responden berumur 11 tahun $(48,3 \%)$ dan lebih dari separuh responden berjenis kelamin laki-laki $(53,3 \%)$. Sebagian besar responden melaksanakan sarapan $(60,0 \%)$, sedangkan yang memiliki daya konsentrasi tinggi $64,2 \%$.

Manfaat yang diperoleh dari kebiasaan sarapan menurut Frisvold (2015) yaitu dapat menyediakan karbohidrat yang siap digunakan untuk meningkatkan kadar gula darah. Dengan kadar gula darah yang normal, maka semangat dan konsentrasi bisa lebih baik. Sarapan memberikan kontribusi penting akan beberapa zat gizi yang diperlukan tubuh karena kekurangan zat gizi dapat mempengaruhi perkembangan otak dan penurunan konsentrasi. Pada penelitian ini responden yang 
Tabel 1. Karakteristik Responden Kebiasaan Sarapan dan Daya Konsentrasi

\begin{tabular}{lrr}
\hline \multirow{2}{*}{ Variabel } & \multicolumn{2}{c}{ Jumlah } \\
\cline { 2 - 3 } Umur (Thn) & $\mathrm{n}$ & $\%$ \\
9 & 3 & 5,0 \\
10 & 14 & 23,3 \\
11 & 29 & 48,3 \\
12 & 14 & 23,3 \\
Jenis Kelamin & & \\
$\quad$ Laki-laki & 32 & 53,3 \\
$\quad$ Perempuan & 28 & 46,7 \\
Daya Konsentrasi & & \\
$\quad$ Tinggi & 39 & 65,0 \\
$\quad$ Rendah & 21 & 35,0 \\
Kebiasaan Sarapan & & \\
$\quad$ Ya & 36 & 60,0 \\
$\quad$ Tidak & 24 & 40,0 \\
\hline
\end{tabular}

terbiasa sarapan pagi memiliki daya konsentrasi tinggi sebanyak $86,1 \%$. Dari hasil statistik chi square diperoleh nilai $\mathrm{p}<0,001$ berarti ada hubungan antara kebiasaan sarapan dengan daya konsentrasi siswa (Tabel 3).

Menurut Gajre, dkk (2008) anak yang tidak terbiasa makan pagi akan berdampak pada konsentrasi mengerjakan tugas di kelas. Hal ini akan berakibat pada menurunnya prestasi di sekolah. Glukosa merupakan sumber energi utama untuk kerja otak. Apabila kadar glukosa turun, glukosa-6-fosfat di hati akan diubah menjadi glukosa sehingga kadar glukosa darah meningkat. Jaringan lain tidak mempunyai enzim glukosa-6fosfatase sehingga tidak dapat mengubah glukosa6-fosfat menjadi glukosa. Glukosa-6-fosfat akan mengalami katabolisme melalui EmbdenMeyerhoff Pathway dan Heksosamonofosfat-shun. Apabila persediaan glukosa darah turun, hati akan mengubah sebagian dari glikogen menjadi glukosa dan mengeluarkannya ke dalam aliran darah. Glukosa ini akan dibawa oleh darah ke seluruh bagian tubuh yang memerlukan salah satunya otak. Hasil penelitian ini sesuai dengan beberapa penelitian sebelumnya tentang hubungan kebiasaan sarapan pagi dengan konsentrasi. Hasil penelitian Muchtar, dkk. (2011) pada anak sekolah di kota Pontianak menunjukkan bahwa terdapat hubungan konsentrasi berpikir menggunakan metode digit symbol test dan digit span test antara anak yang sarapan dengan anak yang tidak sarapan.

Lebih dari separuh responden memiliki tingkat kecukupan energi $(51,7 \%)$ dan $\mathrm{Fe}(53,3 \%)$ yang inadekuat. Tingkat konsumsi protein, karbohidrat, lemak dan vitamin $\mathrm{C}$ yang adekuat secara berturutturut yaitu $60,8 \%, 63,3 \%, 61,5 \%$ dan $58,3 \%$. Menurut Giovannini, dkk. (2008) kurangnya kecukupan energi dapat disebabkan oleh kualitas makan pagi yang tidak memenuhi syarat. Energi yang diperoleh dari karbohidrat, lemak dan protein melalui makanan sehari-hari digunakan untuk membantu kerja organ tubuh, sehingga fungsi tubuh dapat berjalan normal dan dapat melakukan kegiatan seperti bermain, belajar dan melakukan aktifitas yang lain. Simpanan glikogen yang berasal dari hidangan makan malam akan habis 2-4 jam setelah anak bangun pagi, sediaan glikogen mulai menipis (O’Neil, dkk., 2014).

Sebagian besar responden dengan daya konsentrasi tinggi memiliki tingkat kecukupan zat gizi yang adekuat. Hasil analisis statistik

Tabel 2. Tingkat Kecukupan Zat Gizi dan Cairan

\begin{tabular}{lcc}
\hline \multicolumn{1}{c}{ Tingkat Kecukupan } & $\mathbf{n}$ & $\mathbf{\%}$ \\
\hline Tingkat Kecukupan Energi & & \\
$\quad$ Inadequate & 31 & 51,7 \\
$\quad$ Adequate & 29 & 48,3 \\
Tingkat Kecukupan KH & & \\
$\quad$ Inadequate & 22 & 36,7 \\
$\quad$ Adequate & 38 & 63,3 \\
Tingkat Kecukupan Protein & & \\
$\quad$ Inadequate & 24 & 40,0 \\
$\quad$ Adequate & 36 & 60.0 \\
Tingkat Kecukupan Lemak & & \\
$\quad$ Inadequate & 23 & 38,3 \\
$\quad$ Adequate & 37 & 61,9 \\
Tingkat Kecukupan Fe & & \\
$\quad$ Inadequate & 32 & 53,3 \\
Adequate & 28 & 46,7 \\
Tingkat Kecukupan Vit C & & \\
Inadequate & 25 & 41,7 \\
Adequate & 35 & 58,3 \\
Tingkat Kecukupan Cairan & & \\
$\quad$ < 1,8L & 34 & 56,7 \\
$\geq 1,8 \mathrm{~L}$ & 26 & 43,3 \\
\hline
\end{tabular}


menunjukkan adanya hubungan antara energi, karbohidrat, protein, $\mathrm{Fe}$ dan vitamin $\mathrm{C}$ dengan daya konsentrasi (Tabel 3).

Frekuensi makan akan menentukan jumlah makanan yang masuk ke dalam tubuh seseorang sehingga akan menentukan kecukupan zat gizi. Energi merupakan salah satu hasil metabolisme karbohidrat, protein dan lemak. Sumber energi makanan berasal dari karbohidrat, protein dan lemak menghasilkan kalori yang berbeda-beda. Karbohidrat $4 \mathrm{kkal} / \mathrm{g}$, protein $4 \mathrm{kkal} / \mathrm{g}$, dan lemak 9 kkal/g (Levitsky dan Pacanowski, 2013). Kondisi ini berkaitan dengan penggunaan glukosa sebagai sumber energi. Dalam keadaan normal sistim saraf pusat hanya dapat menggunakan glukosa sebagai sumber energi. Dalam proses absorbsi, glukosa diabsorbsi secara aktif menggunakan alat angkut protein dan energi. Sehingga jika konsumsi energi rendah, maka proses pengangkutan glukosa sebagai nutrisi otak akan terganggu (Giovannini, dkk., 2008).

Ketika otak mengalami kekurangan glukosa akan mempengaruhi daya konsentrasi. Sarapan pagi harus memiliki kualitas makanan serta pilihan sumber makanan yang terbaik serta memenuhi sebanyak 20-35\% dari kecukupan energi harian atau $1 / 4$ kalori sehari, tepat jumlahnya serta waktu pemberian (Judarwanto, 2011).

Menurut Fadda, dkk. (2012) sel-sel otak membutuhkan cairan yang bisa dipenuhi oleh air putih. Air putih bisa menjaga fungsi otak dengan baik misalnya untuk menjaga daya konsentrasi, berpikir lebih cepat, dan tidak mudah lupa atau pikun. Cairan dan asupan oksigen yang mengalir pada bagian otak akan berkurang jika kekurangan cairan. Hal ini bisa membuat sel-sel otak tidak

Tabel 3. Hubungan Kebiasaan Sarana, Tingkat Kecukupan Zat Gizi dan Cairan, dengan Daya Konsentrasi

\begin{tabular}{|c|c|c|c|c|c|c|c|}
\hline \multirow{3}{*}{ Tingkat Kecukupan Zat Gizi } & \multicolumn{6}{|c|}{ Daya Konsentrasi } & \multirow{3}{*}{ p Value } \\
\hline & \multicolumn{2}{|c|}{ Tinggi } & \multicolumn{2}{|c|}{ Rendah } & \multicolumn{2}{|c|}{ Total } & \\
\hline & $\mathrm{n}$ & $\%$ & $\mathrm{n}$ & $\%$ & $\mathbf{N}$ & $\%$ & \\
\hline \multicolumn{8}{|l|}{ Kebiasaan Sarapan } \\
\hline Ya & 31 & 86,1 & 5 & 13,9 & 36 & 100 & 0,0001 \\
\hline Tidak & 8 & 33,3 & 16 & 66,7 & 24 & 100 & \\
\hline \multicolumn{8}{|l|}{ Tingkat Kecukupan Energi } \\
\hline Inadequate & 15 & 48,4 & 16 & 51,6 & 31 & 100 & 0,246 \\
\hline Adequate & 24 & 82,8 & 5 & 17,2 & 29 & 100 & \\
\hline \multicolumn{8}{|l|}{ Tingkat Kecukupan KH } \\
\hline Inadequate & 9 & 40,9 & 13 & 59,1 & 22 & 100 & 0,697 \\
\hline Adequate & 30 & 78,1 & 8 & 21,1 & 38 & 100 & \\
\hline \multicolumn{8}{|l|}{ Tingkat Kecukupan Protein } \\
\hline Inadequate & 11 & 45,8 & 13 & 54,2 & 24 & 100 & 0,001 \\
\hline Adequate & 28 & 77,8 & 8 & 22,2 & 36 & 100 & \\
\hline \multicolumn{8}{|l|}{ Tingkat Kecukupan Lemak } \\
\hline Inadequate & 12 & 52,2 & 11 & 47,8 & 23 & 100 & 0.075 \\
\hline Adequate & 27 & 73,0 & 10 & 27,0 & 37 & 100 & \\
\hline \multicolumn{8}{|l|}{ Tingkat Kecukupan Fe } \\
\hline Inadequate & 14 & 43,8 & 18 & 56,2 & 32 & 100 & 0,001 \\
\hline Adequate & 25 & 89,3 & 3 & 10,7 & 25 & 100 & \\
\hline \multicolumn{8}{|l|}{ Tingkat Kecukupan Vit C } \\
\hline Inadequate & 12 & 48,0 & 13 & 52,0 & 25 & 100 & 0,001 \\
\hline Adequate & 27 & 77,1 & 6 & 22,9 & 35 & 100 & \\
\hline \multicolumn{8}{|l|}{ Tingkat Kecukupan Cairan } \\
\hline$<1,8 \mathrm{~L}$ & 16 & 47,1 & 18 & 52,9 & 34 & 100 & 0,0001 \\
\hline$\geq 1,8 \mathrm{~L}$ & 23 & 88,5 & 3 & 11,5 & 26 & 100 & \\
\hline
\end{tabular}


Tabel 4. Variabel yang Paling Berpengaruh terhadap Daya Konsentrasi

\begin{tabular}{lc}
\hline \multicolumn{1}{c}{ Variabel } & Sig. \\
\hline Sarapan & 0,007 \\
Energi & 0,707 \\
KH & 0,095 \\
Protein & 0,748 \\
Fe & 0,012 \\
Vit C & 0,878 \\
Cairan & 0,142 \\
\hline
\end{tabular}

bisa berkembang, aktif dan berfungsi sebagaimana mestinya. Hasil penelitian menunjukkan lebih dari separuh responden memiliki tingkat kecukupan cairan kurang dari $1,8 \mathrm{~L}$ per hari $(56,7 \%)$.

Kekurangan cairan tubuh bisa terjadi pada setiap orang, baik itu pada bayi, anak maupun pada orang dewasa. Bila kekurangan cairan tubuh dibiarkan akan berdampak buruk terhadap kesehatan (Je'quier dan Constant, 2010). Sebagian besar responden yang memiliki daya konsentrasi tinggi memiliki tingkat kecukupan cairan lebih dari 1,8L. Hasil uji statistik menunjukkan ada hubungan antara tingkat kecukupan cairan dengan daya konsentrasi siswa (Tabel 3).

Anak-anak memiliki risiko yang lebih tinggi daripada orang dewasa, karena mereka cenderung minum kurang dari setengah asupan cairan harian yang direkomendasikan. Selain itu, anak-anak juga melakukan aktifitas fisik lebih tinggi dibandingkan dengan orang dewasa. (Fadda, dkk., 2012).

Sarapan memberikan kontribusi yang penting terhadap total asupan gizi sehari karena dapat menyumbangkan sekitar $25 \%$ total asupan gizi sehari. Selain itu sarapan yang baik mengandung sumber karbohidrat, protein, serat tinggi dan lemak rendah (Lentini dan Margawati, 2014). Sarapan berpengaruh terhadap daya konsentrasi belajar siswa. Anak yang tidak sarapan mengalami kekosongan lambung selama 10-11 jam (dihitung dari saat ia tidur malam). Anak akan merasa lapar sekitar pukul 09.00-10.00, dan kadar gula pada tubuh menurun (hipoglikemi), sehingga berdampak terhadap penurunan konsentrasi, menurunnya konsentrasi, cepat lelah dan mudah mengantuk saat di kelas. Kondisi ini juga dapat mengakibatkan siswa tidak dapat menyerap materi yang disampaikan oleh guru dan jika dibiarkan tidak sarapan setiap hari akan berdampak semakin parah yaitu menurunnya prestasi belajar siswa disekolah (Fleming, 2010).

Dengan uji regresi logistik didapatkan hasil $\mathrm{p}=0,007$ responden dengan kebiasaan sarapan merupakan variabel yang paling berpengaruh terhadap daya konsentrasi apabila dibandingkan dengan tingkat kecukupan zat gizi (energi, protein dan karbohidrat) dan tingkat kecukupan cairan.

\section{KESIMPULAN DAN SARAN}

Penelitian ini menyimpulkan terdapat hubungan antara kebiasaan sarapan, tingkat kecukupan zat gizi (energi, karbohidrat, protein, $\mathrm{Fe}$ dan vitamin C) dan cairan dengan daya konsentrasi pada siswa sekolah dasar. Berdasarkan uji regresi logistik sarapan merupakan variabel yang paling berpengaruh terhadap daya konsentrasi anak sekolah dasar.

Orang tua perlu menyediakan sarapan bagi siswa secara rutin. Bagi siswa yang tidak sempat sarapan di rumah, sebaiknya orang tua membawakan bekal sekolah.

\section{DAFTAR PUSTAKA}

Fadda, R., Rapinett, G., Grathwohl, D., Parisi, M., Fanari, R., Calò, C.M., \& Schmitt, J. (2012). Effects of drinking supplementary water at school on cognitive performance in children. Appetite, 59(3), 730-737.

Fleming, A.M. (2010). Smart school time recipes. The breakfast, snack, and lunch box cookbook for healthy kids and adults. Nevada: Fleming Ink.

Frisvold, D.E. (2015). Nutrition and cognitive achievement: an evaluation of the school breakfast program. Journal of Public Economics, 124, 91-104. Diakses dari http:// www.sciencedirect.com/science/article/pii/ S0047272714002497.

Gajre, N.S., Fernandez, S., Balakrishna, N., \& Vazir, S. (2008). Breakfast eating habit and its inlfluensce on attention-concentration, immediate memory and school achievement. Indian Pediatr, 45(10), 824-828. Diakses dari https:// www.ncbi.nlm.nih.gov/pubmed/18948652. 
Giovannini, M., Verduci, E., Scaglioni, S., Salvatici, E., Bonza, M., Riva, E., Agostoni, C. (2008). Breakfeast: a good habit, not a repetitive. The Journal of International Medical Research, 36(4), 613-624. Diakses dari https://www.ncbi. nlm.nih.gov/pubmed/18652755.

Hardinsyah \& Aries, M. (2012). Jenis pangan sarapan dan perannya dalam asupan gizi harian anak usia 6-12 tahun di Indonesia. Jurnal Gizi dan Pangan, 7(2), 89-96.

Jéquier, E., Constant, F. (2010). Water as an essential nutrient: The physiological basis of hydration. European Journal of Clinical Nutrition, 64(2), 115-23. Diakses dari https://www.ncbi.nlm.nih. gov/pubmed/19724292.

Judarwanto, W. (2011). Perilaku makan anak sekolah. Diakses dari http://gizi.depkes.go.id/ makalah/download/perilaku\%20makan\%20 anak\%20sekolah.pdf.

Lentini, B., \& Margawati, A. (2014). Hubungan kebiasaan sarapan dan status hidrasi dengan konsentrasi berfikir pada remaja. Journal of Nutrition College, 3(4), 631-637. Diakses dari https://ejournal3.undip.ac.id/index.php/jnc/ article/view/6862/6586.
Levitsky, D.A., \& Pacanowski, C.R. (2013). Effect of skipping breakfast on subsequent energy intake. Jurnal Physiology and Behavior, 119, 9-16. Diakses dari https://www.ncbi.nlm.nih. gov/pubmed/23672851

Muchtar, M., Julia M., \& Gamayanti, I.L. (2011). Sarapan dan jajan berhubungan dengan kemampuan konsentrasi pada anak sekolah. Jurnal Gizi Klinik Indonesia, 8(1), 28-35. Diakses dari https://jurnal.ugm.ac.id/jgki/ article/view/17728.

O’Neil, C.E., Byrd-Bredbenner, C., Hayes, D., Jana, L., Klinger, S.E., \& Stephenson-Martin, S. (2014). The role of breakfast in health : Definition and criteria for a quality breakfast. Journal of The Academy of Nutrition and Dietetics, 114(12), S8-S26.

Soedibyo, S., \& Gunawan, H. (2009). Kebiasaan sarapan di kalangan anak sekolah dasar di poliklinik umum departemen ilmu kesehatan anak. Jurnal Gizi dan Pangan, 11 (1), 80-98.

Syahnur, M., Afrida, \& Askar, M. (2013). Hubungan kebiasaan sarapan pagi dan status gizi dengan prestasi belajar anak di SDN 20 Pangkajene Sidrap, Jurnal Ilmiah Kesehatan Diagnosis, 2(1), 1-7. 